\title{
Cadmium Toxicity Affects Phytochemicals and Nutrient Elements Composition of Lettuce (Lactuca sativa $L_{\text {.) }}$
}

\author{
Sani Ahmad Jibril, ${ }^{1}$ Siti Aishah Hassan, ${ }^{1}$ \\ Che Fauziah Ishak, ${ }^{2}$ and Puteri Edaroyati Megat Wahab ${ }^{1}$ \\ ${ }^{1}$ Crop Science Department, Faculty of Agriculture, Universiti Putra Malaysia, Selangor, Malaysia \\ ${ }^{2}$ Department of Land Management, Faculty of Agriculture, Universiti Putra Malaysia, Selangor, Malaysia \\ Correspondence should be addressed to Sani Ahmad Jibril; sansat6272@gmail.com
}

Received 23 July 2016; Revised 6 December 2016; Accepted 4 January 2017; Published 20 March 2017

Academic Editor: Albino Maggio

Copyright (C) 2017 Sani Ahmad Jibril et al. This is an open access article distributed under the Creative Commons Attribution License, which permits unrestricted use, distribution, and reproduction in any medium, provided the original work is properly cited.

\begin{abstract}
Lettuce varieties Bombilasta BBL and Italian 167 were treated with different concentrations of cadmium $(0,3,6,9$, and $12 \mathrm{mg} / \mathrm{L})$ in a nutrient film technique (NFT) system to study its toxicity on phytochemicals and nutrient elements. Antioxidants analysis which employed DPPH and FRAP, flavonoids, phenolic, vitamin C, malondialdehyde (MDA), and proline indicated significant effects of $\mathrm{Cd}$ treatment on the varieties tested. Different concentration levels of Cd lead to positive interactions in FRAP, phenolic, and MDA but no significant effect in flavonoids, vitamin $\mathrm{C}$, and proline. Contents of macro- and microelements in the varieties were significantly affected with increase in the toxicity levels of Cd in all nutrient elements tested with interactions exhibited for iron, manganese, and zinc.
\end{abstract}

\section{Introduction}

Use of wastewater in agriculture is gaining wider acceptance in recent years for irrigation purposes. Essential plant nutrients and organic matter are targeted in wastewater by farmers to restore soil productivity, especially in the cultivation of vegetable crops [1]. However, heavy metals and other toxic elements which are also found in wastewater are nonessential to plants and may become toxic to them and eventually pass on to humans and other animals via food chain [2].

Cadmium is a powerful environmental pollutant of widespread occurrence that is released into the environment from phosphate fertilizers, cement factories, waste incinerators, urban traffic, heating systems, power stations, and metal working industries. David and Eric [3] estimated that about 660 metric tons of $\mathrm{Cd}$ per year is being applied to soils on global basis through use of phosphatic fertilizers. Uptake of $\mathrm{Cd}$ in plants is influenced by its bioavailability and concentration which are controlled by redox potential, organic matter, $\mathrm{pH}$, temperature, and concentration of other elements $[4,5]$.
Higher concentrations of $\mathrm{Cd}$ frequently injure roots, damage photosynthetic apparatus, hinder growth of the plants, and decrease nutrients and water uptake. Stohs et al. [6] and Schützendübel et al. [7] stated that Cd directly or indirectly induces increased formation of reactive oxygen species (ROS), which interfere with the redox status of the cell and cause oxidative damage to proteins, lipids, and other biomolecules. Cadmium being a strong pollutant and a quick dissolving substance can affect all life forms. Shah and Dubey [8] reported a sharp decline in crop productivity in soils contaminated with $\mathrm{Cd}$, indicating $\mathrm{Cd}$ as a serious problem for agriculture.

Stroiński [9] described that Cd may exert its inhibitory effect in the cells in two different ways: it may bind to specific groups of proteins and lipids inhibiting their normal function and it may induce free radical formation inducing oxidative stress. The former may occur at the transport and channel proteins of membranes disturbing the uptake of many other macro- and microelements while the latter is proved by the inactivation of antioxidant enzymes by $\mathrm{Cd}$. Destruction of the cell membranes changes the ratio of essential elements 
and causes the decrease in their concentration; for example, $\mathrm{Cd}$ inhibits the transport of iron (Fe) into the shoot. Zhang and Huang [10] reported that $\mathrm{Cd}$ may have antagonistic or synergistic effect on the macro- and microelements in 16 wheat lines.

Plants respond to many abiotic stresses like $\mathrm{Cd}$ by accumulating free amino acids. Proline is one of the amino acids that accumulates in large amounts in response to environmental stresses followed by other amino acids, such as asparagine, isoleucine, leucine, methionine, and valine derived from asparatic acid [11]. Production of proline in Cd stressed plants is important in insuring the maintenance of water balance and protection of enzymes and biomolecules in addition to detoxification of reactive oxygen species. Peroxidation of polyunsaturated fatty acids of membrane lipids by reactive oxygen species is induced by Cd which eventually increases membrane fluidity and membrane permeability [12]. Increase in the levels of malondialdehyde (MDA) in cells of plants is an indication of oxidative stress otherwise known as lipid peroxidation involving oxidative degradation of polyunsaturated fatty acyl residues of membranes [13]. Plants possess antioxidative mechanism comprising antioxidative molecules and enzymes to protect themselves from oxidative damage caused by harmful reactive oxygen species like all aerobic organisms. Shah et al. [14] stated that the increased activity of antioxidative enzymes in metal exposed plants appears to serve as an important component of antioxidant defense mechanism of plants to combat metalinduced oxidative injury. Several researchers [15-18] have reported in different plant species the involvement of glutathione and ascorbic acid in the tolerance of plants to $\mathrm{Cd}$ phytotoxicity. Seregin and Ivanov [19] stated that the decline in net photosynthetic rate in Cd exposed plants results from the distorted chloroplast ultrastructure, restrained synthesis of chlorophylls, plastoquinone, and carotenoids, disturbed electron transport, and inhibited activities of Calvin cycle enzymes and carbon dioxide deficiency in the cells.

The aim of this study was to determine the effect of Cd treatments on phytochemicals and nutrient elements composition of lettuce, which among the two varieties is least and most accumulating of $\mathrm{Cd}$, and assess element present in the varieties.

\section{Materials and Methods}

2.1. Planting Material and Growing Technique. Lettuce (Lactuca sativa L.) seeds of Italian variety 167 and Bombilasta $(\mathrm{BBL})$ were planted and raised for two weeks under a rain shelter with a temperature range of $24-38^{\circ} \mathrm{C}$ and relative humidity of 52 to $94 \%$ under light intensity of $300 \mu \mathrm{mol} \mathrm{m} \mathrm{m}^{-1}$. Seedlings were transferred to circulating troughs irrigated with Cooper's nutrient formulation solution [20] of mg/L : $236 \mathrm{~N}, 60 \mathrm{P}, 300 \mathrm{~K}, 185 \mathrm{Ca}, 50 \mathrm{Mg}, 68 \mathrm{~S}, 12 \mathrm{Fe}$ (EDTA), 2.0 Mn, 0.1 Zn, 0.1 Cu, 0.3 B, and 0.2 Mo, using a nutrient film technique (NFT) system and maintaining a $\mathrm{pH}$ of 5.5-6.5 and E.C. of 1.5-2.5 dS/m. Seedlings were allowed to stabilize for one week after transplanting before treatment.
2.2. Experimental Design and Treatments. The experiment was factorial, arranged in a randomized complete block design (RCBD) with three replications. Five levels of $\mathrm{Cd}(0$, $3,6,9$, and $12 \mathrm{mg} / \mathrm{L}$ ) in the form of $\mathrm{CdCl}_{2}$ and two lettuce varieties (BBL and Italian 167) were used. There were 21 plants of each variety per replication for each Cd level and 6 out of these plants were randomly collected at 8 weeks after treatment for determination of nutrient elements and phytochemicals.

2.3. Plant Tissue Analysis. Fresh leaf samples collected from third leaf of selected plants were put in a large brown envelope and quickly transferred to a cooler box and transported to the laboratory. Proline content was determined according to the method of Bates et al. [21], while free radical scavenging assay (DPPH) and ferric reducing antioxidant power assay (FRAP) were done according to Wong et al. [22] and lipid peroxidation (MDA) was done according to Heath and Packer [23]. Plant nutrient analysis was done according to the procedure described by Motsara and Roy [24] to analyze nutrient contents. Total phenolic acid and total flavonoid determination was conducted as described by Marinova et al. [25]. Total phenolic acid content assay was carried out using Folin-Ciocalteu agent, while total flavonoid assay was conducted using aluminium chloride colorimetric method and total vitamin $\mathrm{C}$ content was measured using modified method of Davies and Masten [26].

2.4. Statistical Methods. Data generated were means of three replicates. Statistical analysis was performed using statistical software package (SAS version 9.2, SAS Institute Incorporated, Cary, North Carolina, USA). Comparison among treatments was evaluated by ANOVA, and least significant difference (LSD) was used in separating means. Differences between the treatments were considered significant at $p<$ 0.05 .

\section{Results and Discussion}

3.1. Effect of Cd on Nutrient Composition. The nutrient concentrations among the varieties and Cd treatments are presented in Table 1. Essential nutrients and Cd accumulation in plant tissue depends on the lettuce varieties. Variety Italian 167 accumulated significantly higher amount of all nutrients with exception of $\mathrm{Mg}$ than variety BBL. Iron and $\mathrm{Cu}$ content in variety Italian 167 were $48.9 \%$ and $47 \%$, respectively, higher than in BBL. Unfortunately variety Italian 167 also absorbed $31.5 \%$ more $\mathrm{Cd}$ than variety BBL. As a vegetable, higher content of $\mathrm{Cd}$ in lettuce tissue must be avoided. The toxicity effect of Cd on plant eventually will pass on to humans and other animals via food chain [2].

The degree of contamination and plant species, which have different tolerance to toxic heavy metals, determined the effect of $\mathrm{Cd}$ on nutrient uptake in plants. Genotypic variations in shoot $\mathrm{Cd}$ concentration in 146 rice accessions from rice core-collection have been examined by Ueno et al. [27] and a large variation in the shoot Cd accumulation and Cd tolerance was found. Rahat et al. [28] stated that there 
TABLE 1: Effect of Cd concentrations on nutrient element composition in lettuces.

\begin{tabular}{|c|c|c|c|c|c|c|c|c|c|c|}
\hline \multirow{2}{*}{ Treatment } & \multicolumn{5}{|c|}{ Macroelements (\%/DW) } & \multicolumn{5}{|c|}{ Microelements ( $\mu \mathrm{g} / \mathrm{g} \mathrm{DW})$} \\
\hline & $\mathrm{N}$ & $\mathrm{P}$ & $\mathrm{K}$ & $\mathrm{Ca}$ & $\mathrm{Mg}$ & $\mathrm{Fe}$ & $\mathrm{Mn}$ & $\mathrm{Cu}$ & $\mathrm{Zn}$ & $\mathrm{Cd}$ \\
\hline \multicolumn{11}{|c|}{ Variety } \\
\hline BBL & $2.59 \mathrm{~b}$ & $0.34 \mathrm{~b}$ & $5.74 \mathrm{~b}$ & $0.97 b$ & $0.52 \mathrm{a}$ & $92.82 b$ & $60.60 \mathrm{~b}$ & $7.03 b$ & $36.53 b$ & $77.18 b$ \\
\hline Italian 167 & $2.99 \mathrm{a}$ & $0.43 \mathrm{a}$ & $6.41 \mathrm{a}$ & $1.17 \mathrm{a}$ & $0.53 \mathrm{a}$ & $137.73 \mathrm{a}$ & 75.61a & $10.26 \mathrm{a}$ & $44.75 \mathrm{a}$ & $101.48 \mathrm{a}$ \\
\hline Significance & $* *$ & $* *$ & $* *$ & $* *$ & ns & $* *$ & $* *$ & $* *$ & $* *$ & $* *$ \\
\hline \multicolumn{11}{|c|}{ Cadmium concentration $(\mathrm{mg} / \mathrm{L})$} \\
\hline 0 & $4.00 \mathrm{a}$ & $0.55 \mathrm{a}$ & $7.95 \mathrm{a}$ & $1.53 \mathrm{a}$ & $0.56 \mathrm{a}$ & $152.73 a$ & $110.04 \mathrm{a}$ & $12.68 \mathrm{a}$ & $52.54 \mathrm{a}$ & $0.01 \mathrm{e}$ \\
\hline 3 & 3.61a & $0.49 b$ & $7.12 \mathrm{~b}$ & $1.28 \mathrm{~b}$ & $0.55 \mathrm{a}$ & $104.76 \mathrm{~b}$ & $88.21 \mathrm{~b}$ & $9.78 b$ & $45.66 \mathrm{~b}$ & $74.92 \mathrm{~d}$ \\
\hline 6 & $3.01 \mathrm{~b}$ & $0.42 c$ & $5.20 c$ & $1.05 c$ & $0.42 \mathrm{~b}$ & $86.12 c$ & $63.00 \mathrm{c}$ & $5.53 c$ & $41.92 \mathrm{c}$ & $95.95 \mathrm{c}$ \\
\hline 9 & $2.18 c$ & $0.30 \mathrm{~d}$ & $4.62 \mathrm{~d}$ & $0.90 c$ & $0.31 c$ & $59.04 \mathrm{~d}$ & $47.08 \mathrm{~d}$ & $2.66 \mathrm{~d}$ & $34.87 \mathrm{~d}$ & $120.50 \mathrm{~b}$ \\
\hline 12 & $1.16 \mathrm{~d}$ & $0.17 \mathrm{e}$ & $3.48 \mathrm{e}$ & $0.59 \mathrm{~d}$ & $0.27 \mathrm{~d}$ & $29.69 \mathrm{e}$ & $24.19 \mathrm{e}$ & $0.57 \mathrm{e}$ & $27.25 \mathrm{e}$ & $152.97 \mathrm{a}$ \\
\hline Significance & $* *$ & $* *$ & $* *$ & $* *$ & $* *$ & $* *$ & $* *$ & $* *$ & $* *$ & $* *$ \\
\hline & & & & & 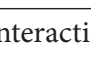 & & & & & \\
\hline
\end{tabular}

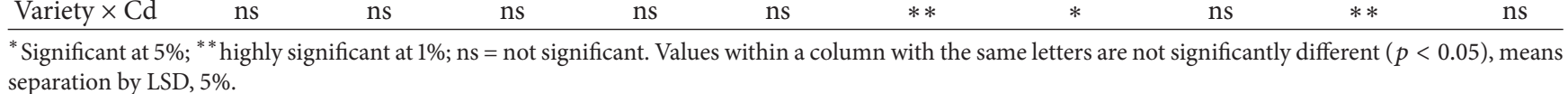
separation by LSD, $5 \%$.

are significant differences in Cd tolerance among species and varieties but contradictions exist between the results of different experiments, which may be attributed to the inherent differential capacity of different species and varieties for Cd accumulation and partitioning in root and shoot and also the ability to restrict $\mathrm{Cd}$ in roots.

Contents of macro- and microelements in both varieties were significantly affected by $\mathrm{Cd}$ levels. Increase in the concentration of Cd to $12 \mathrm{mg} / \mathrm{L}$ resulted in the decrease of all macro essential elements measured with a range of 72 , $69,56,61$, and $52 \%$ for $\mathrm{N}, \mathrm{P}, \mathrm{K}, \mathrm{Ca}$, and $\mathrm{Mg}$, respectively, compared with the control, while a decrease of $80 \%, 78 \%$, $95 \%$, and $48 \%$ was found for $\mathrm{Fe}, \mathrm{Mn}, \mathrm{Cu}$, and $\mathrm{Zn}$, respectively, indicating that $\mathrm{Cd}$ is a strong antagonist to these metal ions (Table 1). The toxicity effect of $\mathrm{Cd}$ to nutrient elements was more pronounced at $6 \mathrm{mg} / \mathrm{L}$ and at the higher concentrations. As the concentration of Cd increases, nutrients elements contents were decreased. Comparing the results with reference sufficiency ranges for plant analysis reported by Campbell [29] indicated a short fall in all macroelements except Ca. However, values obtained in microelements do not fall below the nutrient sufficiency range for lettuce. Maria et al. [30] exposed lettuce to $\mathrm{Cd}$ concentration of 10 and $50 \mu \mathrm{M}$ and they found a significant decrease in leaf nutrient content of several essential elements such as $\mathrm{Fe}$ and $\mathrm{Mn}$, but only at the highest concentration of $\mathrm{Cd}$ treatment, a significant reduction of Mn was observed in roots, suggesting Cd interferes with the translocation of macro- and micronutrients to the leaves.

There was no interaction effect between Cd level and variety in respect to $\mathrm{Cd}$ content in plant even though from our observation the varieties displayed different severity of chlorotic symptoms and plant size in response to Cd toxicity. However interaction of both factors was found significant in $\mathrm{Fe}, \mathrm{Mn}$, and $\mathrm{Zn}$. Variety Italian 167 showed higher percentage of reduction in Fe (Figure 1) and Mn (Figure 2(a)) for each increment of $\mathrm{Cd}$ concentration as compared to BBL variety,

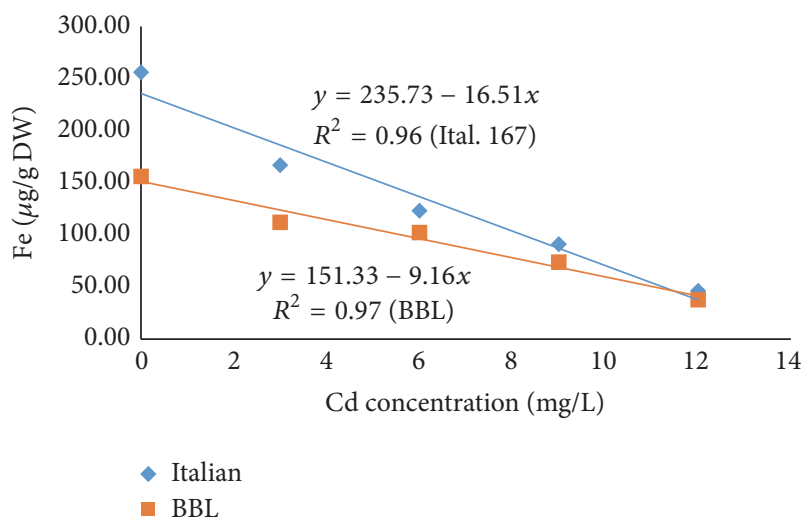

FIGURE 1: Interaction effect of Cd concentration and lettuce varieties on Fe content.

whereas, for $\mathrm{Zn}$, higher reduction at lower $\mathrm{Cd}$ concentrations was exhibited by variety BBL (Figure 2(b)).

Uptake of cations like $\mathrm{K}^{+}, \mathrm{Ca}^{2+}, \mathrm{Mg}^{2+}, \mathrm{Mn}^{2+}, \mathrm{Zn}^{2+}$, and $\mathrm{Fe}^{2+}$ is affected by Cd. Llamas et al. [31] reported that Cd being a divalent cation may compete with $\mathrm{Ca}, \mathrm{Mg}$, or $\mathrm{Fe}$ in their transport across membrane. According to PerfusBarbeoch et al. [32], members of the ZIP and NRAMP or $\mathrm{Ca}$ channels and transporters which are responsible for the uptake of essential elements are involved in the transport of $\mathrm{Cd}$ via the same route. Imbalance in the nutrient level and growth inhibition is ultimately as a consequence of the above competition between nutrients and toxic metals for binding sites in different compartments, for example, plasma membrane and cell wall. Sun and Shen [33] explained that the decrease in concentrations of $\mathrm{Mn}, \mathrm{Fe}, \mathrm{Mg}, \mathrm{S}$, and $\mathrm{P}$ in leaves of Cd-sensitive cultivars under Cd stress is revealed to be the important reason for the restraint of leaf photosynthesis and the decrease of cabbage growth. 


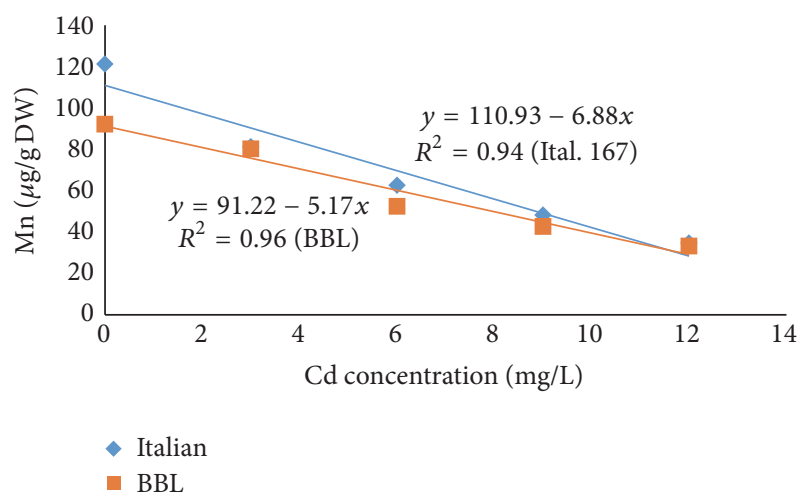

(a)

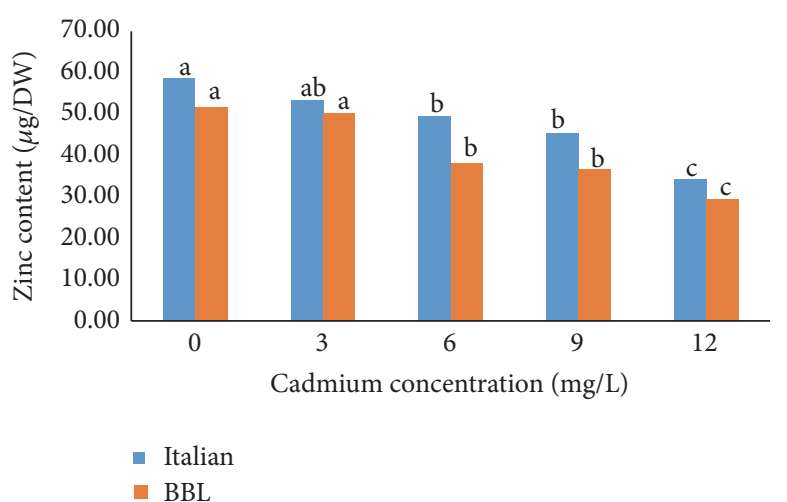

(b)

Figure 2: Interaction effect of $\mathrm{Cd}$ concentrations and lettuce varieties on $\mathrm{Mn}$ (a) and $\mathrm{Zn}$ (b) contents. Values within a variety with the same letters are not significantly different $(p<0.05)$, means separation by LSD, $5 \%$.

TABLE 2: Effect of cadmium concentration on free radical scavenging assay (DPPH) and ferric reducing antioxidant power assay (FRAP), total flavonoids, and total phenolics in lettuce.

\begin{tabular}{|c|c|c|c|c|}
\hline Treatment & DPPH scavenging (\%) & FRAP assay (\%) & Total flavonoids (mg CE/g) & Total phenolic (mg GAE/g) \\
\hline \multicolumn{5}{|c|}{ Variety } \\
\hline $\mathrm{BBL}$ & $67.53 b$ & $63.26 \mathrm{~b}$ & $4.34 \mathrm{~b}$ & $2.71 b$ \\
\hline Italian 167 & $82.30 \mathrm{a}$ & $74.22 \mathrm{a}$ & $5.55 \mathrm{a}$ & $4.57 \mathrm{a}$ \\
\hline Significance & $* *$ & $* *$ & $* *$ & $* *$ \\
\hline \multicolumn{5}{|c|}{ Cadmium concentration $(\mathrm{mg} / \mathrm{L})$} \\
\hline 0 & 69.31d & 63.31d & $1.05 \mathrm{e}$ & $1.20 \mathrm{e}$ \\
\hline 3 & $71.04 \mathrm{~d}$ & $65.25 \mathrm{~d}$ & $1.93 \mathrm{~d}$ & $1.85 \mathrm{~d}$ \\
\hline 6 & $73.18 \mathrm{c}$ & $68.37 \mathrm{c}$ & $4.91 \mathrm{c}$ & $3.55 \mathrm{c}$ \\
\hline 9 & $76.82 b$ & $71.12 b$ & $7.57 b$ & $5.04 \mathrm{~b}$ \\
\hline 12 & $84.24 \mathrm{a}$ & $75.63 a$ & $9.26 \mathrm{a}$ & $6.57 \mathrm{a}$ \\
\hline Significance & $* *$ & $* *$ & $* *$ & $* *$ \\
\hline \multicolumn{5}{|c|}{ Interaction } \\
\hline Variety $\times \mathrm{Cd}$ & ns & ns & ns & $* *$ \\
\hline
\end{tabular}

Significant at $5 \% ;{ }^{* *}$ highly significant at $1 \%$; ns = not significant. Values within a column with the same letters are not significantly different $(p<0.05)$, means separation by LSD, $5 \%$.

3.2. Effect of $\mathrm{Cd}$ on Antioxidants. Determination of antioxidant activity in the Cd treated lettuce plants was conducted employing free radical scavenging assay (DPPH) and ferric reducing antioxidant power assay (FRAP) methods of Wong et al. [22]. Based on both antioxidant activity assays, variety Italian 167 has significantly higher antioxidants than variety BBL (Table 2). Significant differences were observed within the Cd treatments. There was $14.9 \%$ increase in DPPH free radical scavenging activity when stressed with $12 \mathrm{mg} / \mathrm{L} \mathrm{Cd}$ compared with the control plants. Increase in the concentration of Cd brought about an increase in the antioxidant activity. Similar trend was observed in ferric reducing antioxidant power assay (FRAP). These two methods provided similar results as they did not reveal much differences between them, which confirmed the claim of Thaipong et al. [34] that DPPH free radical scavenging assay and FRAP assay have no significant difference in their determinations.
3.3. Effect of $\mathrm{Cd}$ on Phytochemicals. It would be desirable to know the nature of phytochemical in plants responded to detoxifying heavy metals. In this study, the photochemical compounds bioavailability in lettuce produced is discussed in total phenolic and flavonoid, vitamin C, malondialdehyde (MDA), and proline. The significance level effects of $\mathrm{Cd}$ and lettuce varieties on phytochemical compounds in leaves are presented in Tables 2 and 3.

Levels of flavonoids, phenolics, and malondialdehyde increased tremendously when subjected to higher Cd concentration of $12 \mathrm{mg} / \mathrm{L}$, but vitamin $\mathrm{C}$ level significantly decreased compared with the control plants. Interaction effects of $\mathrm{Cd}$ and lettuce varieties were observed in total phenolics (Figure 3(a)) and lipid peroxidation (Figure 3(b)) indicating higher increase in $\mathrm{Cd}$ resulted in higher production of the phytochemicals in trying to protect the plants from further damage by reactive oxygen species. Italian lettuce 167 variety responded more in the production of 
TABLE 3: Effect of cadmium concentration on vitamin C, malondialdehyde (MDA), and proline in lettuce.

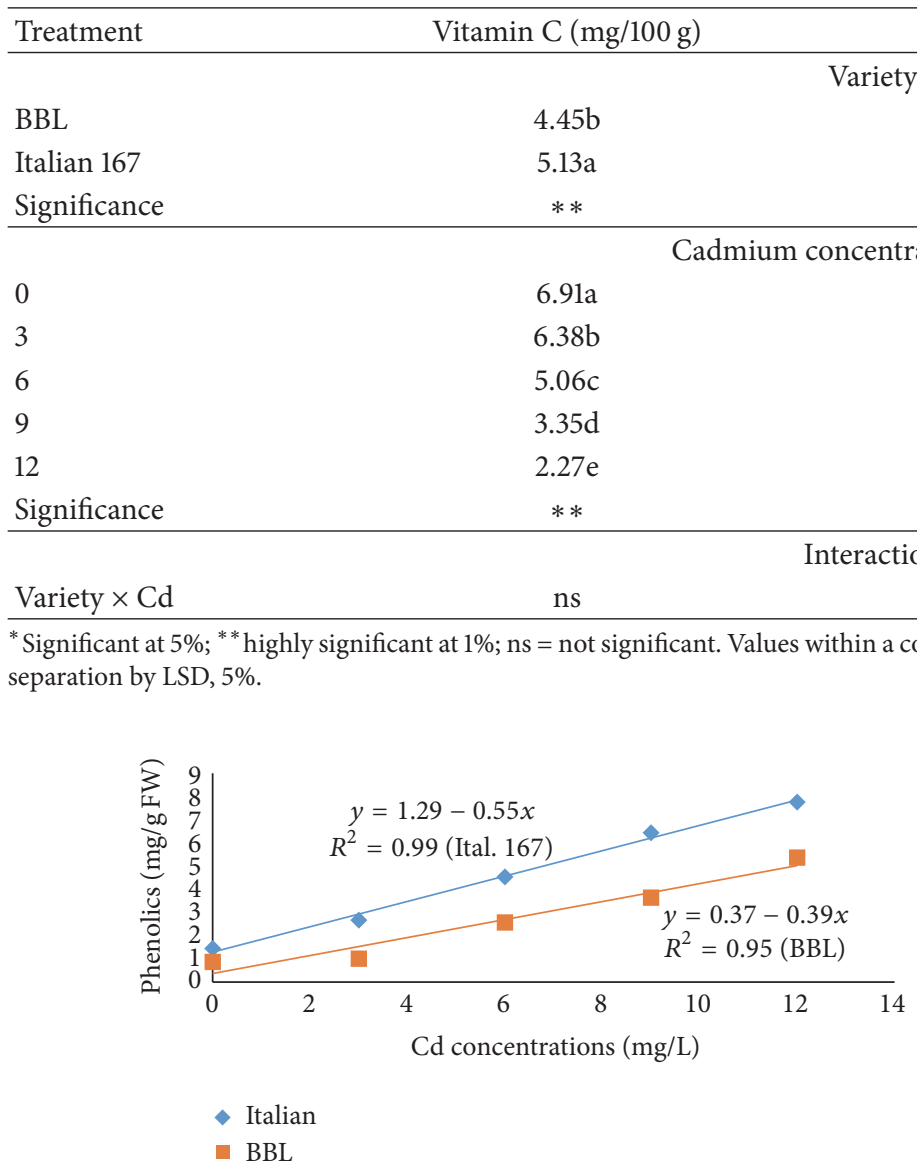

(a)

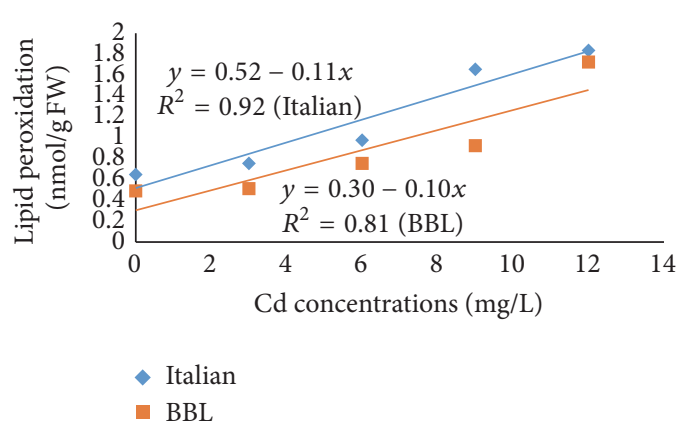

(b)

FIGURE 3: Interaction effect of Cd concentrations on (a) phenolic and (b) lipid peroxidation (MDA) contents of lettuce.

phytochemicals to counter the toxicity effect of $\mathrm{Cd}$ than variety BBL. Michalak [35] explained that phenolics, especially flavonoids, can be oxidized by peroxidase and act in the $\mathrm{H}_{2} \mathrm{O}_{2}$-scavenging, phenolic/ascorbate (ASC)/phenolic peroxidase (POX) system when treated with heavy metals. Activation of the antioxidative system of the cell is therefore as a result of heavy metal stresses which increase the reactive molecules in the stressed tissue. Nasim and Dhir [36] in an earlier study suggested the role heavy metals may play in triggering plant genes to alter the nature of secondary metabolites. Inducement of oxidative stress by heavy metals triggers signaling pathways that affect production of specific plant metabolites. Belen et al. [37] reported similar pattern of increase in the contents of phenolics and flavonoids of Erica andevalensis treated with acute doses of Cd. Padayatty et al. [38], Foyer [39], and Bielski et al. [40] reported that vitamin $\mathrm{C}$ is one of the major antioxidant agents in removing free radicals along with vitamins $\mathrm{E}$ and $\mathrm{A}$ and the minerals selenium and zinc. According to Sujogya [41], vitamin C is a second-line defense antioxidant which interacts directly with radicals like $\mathrm{O}_{2}{ }^{-}, \mathrm{H}_{2} \mathrm{O}_{2}$, and $\mathrm{OH}$. Vitamin $\mathrm{C}$ and $\alpha$ tocopherol both help to minimize the consequences of lipid peroxidation in membranes. In this study, reduction of $67 \%$ and $52 \%$ of vitamin $\mathrm{C}$ was observed when lettuce was exposed to $12 \mathrm{mg} / \mathrm{L}$ and $9 \mathrm{mg} / \mathrm{L}$ of $\mathrm{Cd}$, respectively, as compared to control (Table 3).

Cadmium induced oxidative damage involves peroxidation of polyunsaturated fatty acids of membrane lipids by reactive oxygen species generated by $\mathrm{Cd}$ leading to membrane fluidity and membrane permeability [42]. As an index of lipid peroxidation under stress condition, the level of malondialdehyde (MDA) is routinely used to evaluate its effect in plant samples. Increased level of MDA to 3-fold for lettuce grown in $12 \mathrm{mg} / \mathrm{L} \mathrm{Cd}$ over the control coincided with the findings of Shah et al. [14] in Cd stressed rice seedlings. An increase of about 1.4 to 1.6 times in malondialdehyde (MDA) content under $500 \mu \mathrm{M} \mathrm{Cd}$ treatment in two rice seedlings cvs Ratna and Jaya was reported by Shah et al. [14] indicating enhanced peroxidation of lipid due to $\mathrm{Cd}$. Excessive accumulation of MDA when plants were subjected to Cd stress was reported by Lozano-Rodríguez et al. [43], Chaoui et al. [44], and Wu et al. [45].

According to Shah and Dubey [46] and Verma [47] one mechanism by which many plants respond to detoxifying heavy metals is the production of proline. Difference of $15 \%$ in proline content recorded between two varieties (Table 3 ) 
suggested potential effort to overcome the toxic effect of $\mathrm{Cd}$ in the lettuce varieties, thus protecting its delicate tissues and organs from severe damage by ROS. Srivastava et al. [48] reported that proline helps plants to recover from environmental stresses and its accumulation might be induced as a result of reactive oxygen species (ROS). Alia et al. [49] added that proline reduces oxidative damage through the mechanisms of physical quenching of singlet oxygen and chemical reaction with hydroxyl radicals. Proline also acts as a defense mechanism for survival of stressed plants by binding with metal ions due to its chelating ability. Although higher Cd levels resulted in no significant effect on proline content, there was $27 \%$ increase in proline at $9 \mathrm{mg} / \mathrm{L} \mathrm{Cd}$ compared to control. Similar accumulation of proline in the shoots of Brassica juncea, Triticum aestivum, and Vigna radiate was demonstrated by Dhir et al. [50] in response to Cd toxicity but decreased with the exposure to Cd in hydrophytes (Ceratophyllum, Wolffia, and Hydrilla).

\section{Conclusion}

From the above results, it can be concluded that Cd stresses have adverse effect on phytochemicals and nutrient elements of lettuce when subjected to high concentrations. Cadmium toxicity brought about increase in the activities of antioxidants, secondary metabolites, MDA production, and proline as a defense mechanism to protect the plants against physiological and structural injuries. Nutrient imbalances and reduction in the amount of vitamin $\mathrm{C}$, resulting from the toxic effect of $\mathrm{Cd}$, can alone trigger oxidative stress, nutrient deficiencies, and reduction in plant growth and development of agricultural crops. Italian 167 variety absorbed more Cd than BBL variety, suggesting that Italian 167 variety should not be recommended for planting in Cd polluted environments. Viable strategies should be engaged to counteract the toxic effect of $\mathrm{Cd}$ in agricultural lands to protect crop plants from eventual damaging effects.

\section{Competing Interests}

The authors declare that there is no conflict of interests regarding the publication of this paper.

\section{References}

[1] B. Carl, M. Duncan, D. Pay, and E. Alexandra, Improving Wastewater Use in Agriculture: An Emerging Priority, Water Partnership Program, Water Anchor (ETWWA), The World Bank, Washington, DC, USA, 2010.

[2] I. Hussein, L. Raschid, M. A. Hanjra, F. Marikar, and W. Van der Hoek, "A framework for analyzing socioeconomic, health and environmental impacts of wastewater use in agriculture in developing countries," Working Paper 26, International Water Management Institute (IWMI), Colombo, Sri Lanka, 2001.

[3] M. O. David and T. N. Eric, Physiology of Plants under Stress; Soil and Biotic factors, John Wiley \& Sons, New York, NY, USA, 2000.

[4] S. L. di Toppi and R. Gabbrielli, "Response to cadmium in higher plants," Environmental and Experimental Botany, vol. 41, no. 2, pp. 105-130, 1999.
[5] A. L. Nolan, M. J. McLaughlin, and S. D. Mason, "Chemical speciation of $\mathrm{Zn}, \mathrm{Cd}, \mathrm{Cu}$, and $\mathrm{Pb}$ in pore waters of agricultural and contaminated soils using donnan dialysis," Environmental Science and Technology, vol. 37, no. 1, pp. 90-98, 2003.

[6] S. J. Stohs, D. Bagchi, E. Hassoun, and M. Bagchi, "Oxidative mechanisms in the toxicity of chromium and cadmium ions," Journal of Environmental Pathology, Toxicology and Oncology, vol. 19, no. 3, pp. 201-213, 2000.

[7] A. Schützendübel, P. Schwanz, T. Teichmann et al., "Cadmiuminduced changes in antioxidative systems, hydrogen peroxide content, and differentiation in Scots pine roots," Plant Physiology, vol. 127, no. 3, pp. 887-898, 2001.

[8] K. Shah and R. S. Dubey, "Effect of cadmium on proline accumulation and ribonuclease activity in rice seedlings: role of proline as a possible enzyme protectant," Biologia Plantarum, vol. 40, no. 1, pp. 121-130, 1997.

[9] A. Stroiński, "Some physiological and biochemical aspects of plant resistance to cadmium effect. I. Antioxidative system," Acta Physiologiae Plantarum, vol. 21, no. 2, pp. 175-188, 1999.

[10] J. B. Zhang and W. N. Huang, "Advances on physiological and ecological effects of cadmium on plants," Acta Ecologica Sinica, vol. 20, pp. 514-523, 2000 (Chinese).

[11] D. Aspinall and L. G. Paleg, "Proline accumulation: physiological aspects," in Physiology and Biochemistry of Drought Resistance in Plants, D. Aspinall and L. G. Paleg, Eds., pp. 206241, Academic Press, Samford Valley, Australia, 1981.

[12] L. Xu, Y. Dong, Z. Fan, J. Kong, S. Liu, and X. Bai, "Effects of the application of exogenous NO at different growth stage on the physiological characteristics of peanut grown in Cdcontaminated soil," Journal of Plant Interactions, vol. 9, no. 1, pp. 285-296, 2014.

[13] A. W. Girotti, "Photodynamic lipid peroxidation in biological systems," Photochemistry and photobiology, vol. 51, no. 4, pp. 497-509, 1990.

[14] K. Shah, R. G. Kumar, S. Verma, and R. S. Dubey, "Effect of cadmium on lipid peroxidation, superoxide anion generation and activities of antioxidant enzymes in growing rice seedlings," Plant Science, vol. 161, no. 6, pp. 1135-1144, 2001.

[15] A. H. El-Naggar and M. M. El-Sheekh, "Abolishing cadmium toxicity in Chlorella vulgaris by ascorbic acid, calcium, glucose and reduced glutathione," Environmental Pollution, vol. 101, no. 2, pp. 169-174, 1998.

[16] F. Wu and G. Zhang, "Alleviation of cadmium-toxicity by application of zinc and ascorbic acid in barley," Journal of Plant Nutrition, vol. 25, no. 12, pp. 2745-2761, 2002.

[17] D. Mendoza-Cozatl, S. Devars, H. Loza-Tavera, and R. MorenoSánchez, "Cadmium accumulation in the chloroplast of Euglena gracilis," Physiologia Plantarum, vol. 115, no. 2, pp. 276-283, 2002.

[18] L. Ozturk, S. Karanlik, F. Ozkutlu, I. Cakmak, and L. V. Kochian, "Shoot biomass and zinc/cadmium uptake for hyperaccumulator and non-accumulator Thlaspi species in response to growth on a zinc-deficient calcareous soil," Plant Science, vol. 164, no. 6, pp. 1095-1101, 2003.

[19] I. V. Seregin and V. B. Ivanov, "Physiological aspects of cadmium and lead toxic effects on higher plants," Russian Journal of Plant Physiology, vol. 48, no. 4, pp. 523-544, 2001.

[20] A. J. Cooper, The ABC of Nutrient Film Technique, Grower Books, London, UK, 1979.

[21] L. S. Bates, R. P. Waldren, and I. D. Teare, "Rapid determination of free proline for water-stress studies," Plant and Soil, vol. 39, no. 1, pp. 205-207, 1973. 
[22] S. P. Wong, L. P. Leong, and J. H. William Koh, "Antioxidant activities of aqueous extracts of selected plants," Food Chemistry, vol. 99, no. 4, pp. 775-783, 2006.

[23] R. L. Heath and L. Packer, "Photoperoxidation in isolated chloroplasts. I. Kinetics and stoichiometry of fatty acid peroxidation," Archives of Biochemistry and Biophysics, vol. 125, no. 1, pp. 189-198, 1968.

[24] M. R. Motsara and R. N. Roy, Guide to Laboratory Establishment for Plant Nutrient Analysis, FAO, Viale delle Terme di Caracalla, Italy, 2008.

[25] D. Marinova, F. Ribarova, and M. Atanassova, "Total phenolics and total flavonoids in Bulgarian fruits and vegetables," Journal of the University of Chemical Technology and Metallurgy, vol. 40, pp. 255-260, 2005.

[26] S. H. R. Davies and S. J. Masten, "Spectrophotometric method for ascorbic acid using dichlorophenolindophenol: elimination of the interference due to iron," Analytica Chimica Acta, vol. 248, no. 1, pp. 225-227, 1991.

[27] D. Ueno, E. Koyama, I. Kono, T. Ando, M. Yano, and J. F. $\mathrm{Ma}$, "Identification of a novel major quantitative trait locus controlling distribution of cd between roots and shoots in rice," Plant and Cell Physiology, vol. 50, no. 12, pp. 2223-2233, 2009.

[28] N. Rahat, I. Noushina, M. Asim et al., "Cadmium toxicity in plants and role of mineral nutrients in its alleviation," American Journal of Plant Sciences, vol. 3, pp. 1476-1489, 2012.

[29] C. R. Campbell, Reference Sufficiency Ranges for Plant Analysis in the Southern Region of the United States, Southern Cooperative Series Bulletin \#394, 2000.

[30] C. D. Maria, M. Cristina, M. P. Jose, C. Carlos, G. Berta, and S. Conceicao, "Cadmium toxicity affects photosynthesis and plant growth at different levels," Acta Physiologiae Plantarum, vol. 35, no. 4, pp. 1281-1289, 2013.

[31] A. Llamas, C. I. Ullrich, and A. Sanz, "Cd ${ }^{2+}$ effects on transmembrane electrical potential difference, respiration and membrane permeability of rice (Oryza sativa L) roots," Plant and Soil, vol. 219, no. 1-2, pp. 21-28, 2000.

[32] L. Perfus-Barbeoch, N. Leonhardt, A. Vavasseur, and C. Forestier, "Heavy metal toxicity: cadmium permeates through calcium channels and disturbs the plant water status," Plant Journal, vol. 32, no. 4, pp. 539-548, 2002.

[33] J.-Y. Sun and Z.-G. Shen, "Effects of Cd stress on photosynthetic characteristics and nutrient uptake of cabbages with different Cd-tolerance," Chinese Journal of Applied Ecology, vol. 18, no. 11, pp. 2605-2610, 2007.

[34] K. Thaipong, U. Boonprakob, K. Crosby, L. Cisneros-Zevallos, and D. Hawkins Byrne, "Comparison of ABTS, DPPH, FRAP, and ORAC assays for estimating antioxidant activity from guava fruit extracts," Journal of Food Composition and Analysis, vol. 19, no. 6-7, pp. 669-675, 2006.

[35] A. Michalak, "Phenolic compounds and their antioxidant activity in plants growing under heavy metal stress," Polish Journal of Environmental Studies, vol. 15, no. 4, pp. 523-530, 2006.

[36] S. A. Nasim and B. Dhir, "Heavy metals alter the potency of medicinal plants," Reviews of Environmental Contamination and Toxicology, vol. 203, pp. 139-149, 2010.

[37] M. G. Belen, M. Angeles, and C. Francisco, "Effects of cadmium on phenolic composition and antioxidant activities of Erica andevalensis," Journal of Botany, vol. 2012, Article ID 936950, 6 pages, 2012

[38] S. J. Padayatty, A. Katz, Y. Wang et al., "Vitamin C as an antioxidant: evaluation of its role in disease prevention," Journal of the American College of Nutrition, vol. 22, no. 1, pp. 18-35, 2003.
[39] C. H. Foyer, "Ascorbic acid," in Antioxidants in Higher Plants, R. G. Alscher and J. L. Hess, Eds., pp. 51-58, CRC Press, Boca Raton, Fla, USA, 1993.

[40] B. H. J. Bielski, H. W. Richter, and P. C. Chan, "Some properties of the ascorbate free radical," Annals of the New York Academy of Sciences, vol. 258, pp. 231-237, 1975.

[41] K. P. Sujogya, "Assay guided comparison for enzymatic and non-enzymatic antioxidant activities with special reference to medicinal plants," in Antioxidant Enzyme, pp. 382-385, InTech, Rijeka, Croatia, 2012.

[42] A. Nafees and S. Khan, Cadmium Toxicity and Tolerance in Plants, Alpha Science Intl Ltd, Oxford, UK, 2006.

[43] E. Lozano-Rodríguez, L. E. Hernández, P. Bonay, and R. O. Carpena-Ruiz, "Distribution of cadmium in shoot and root tissues of maize and pea plants: physiological disturbances," Journal of Experimental Botany, vol. 48, no. 306, pp. 123-128, 1997.

[44] A. Chaoui, S. Mazhoudi, M. H. Ghorbal, and E. El Ferjani, "Cadmium and zinc induction of lipid peroxidation and effects on antioxidant enzyme activities in bean (Phaseolus vulgaris L.)," Plant Science, vol. 127, no. 2, pp. 139-147, 1997.

[45] F. Wu, G. Zhang, and P. Dominy, "Four barley genotypes respond differently to cadmium: lipid peroxidation and activities of antioxidant capacity," Environmental and Experimental Botany, vol. 50, no. 1, pp. 67-78, 2003.

[46] K. Shah and R. S. Dubey, "Cadmium alters phosphate level and suppresses activity of phosphorolytic enzymes in germinating rice seeds," Journal of Agronomy and Crop Science, vol. 179, no. 1, pp. 35-45, 1997.

[47] D. P. S. Verma, "Osmotic stress tolerance in plants: role of proline and sulfur metabolisms," in Molecular Responses to Cold, Drought, Heat and Salt Stress in Higher Plants, K. Shinoszaki and K. Yamaguchi-Shinozaki, Eds., pp. 153-168, R.G. Landers, Austin, Tex, USA, 1999.

[48] S. Srivastava, A. K. Srivastava, P. Suprasanna, and S. F. D'Souza, "Comparative biochemical and transcriptional profiling of two contrasting varieties of Brassica juncea L. in response to arsenic exposure reveals mechanisms of stress perception and tolerance," Journal of Experimental Botany, vol. 60, no. 12, pp. 3419-3431, 2009.

[49] Alia, P. Mohanty, and J. Matysik, "Effect of proline on the production of singlet oxygen," Amino Acids, vol. 21, no. 2, pp. 195-200, 2001.

[50] B. Dhir, P. Sharmila, and P. P. Saradhi, "Hydrophytes lack potential to exhibit cadmium stress induced enhancement in lipid peroxidation and accumulation of proline," Aquatic Toxicology, vol. 66, no. 2, pp. 141-147, 2004. 


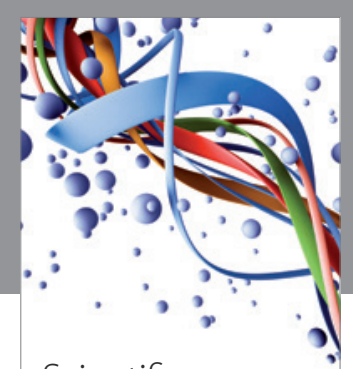

Scientifica
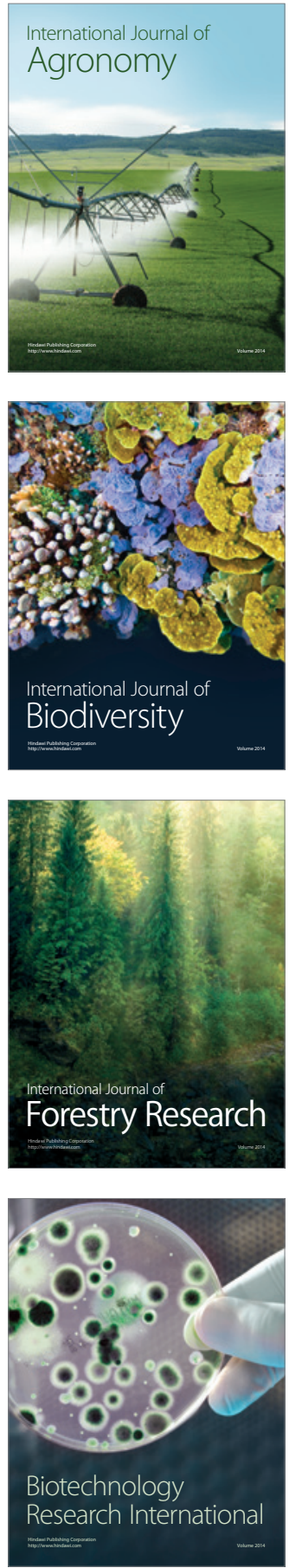
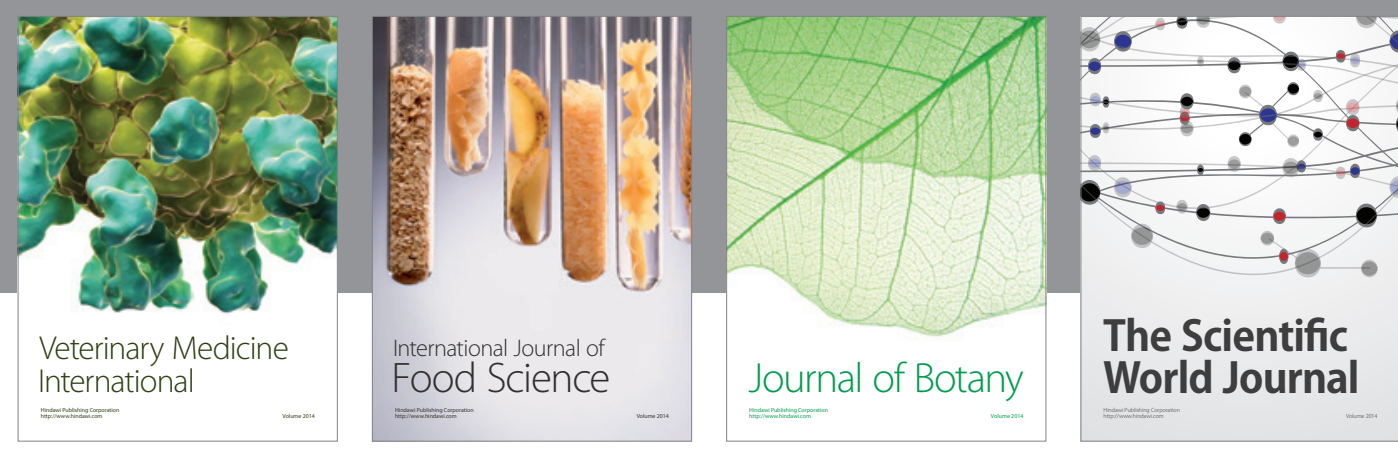

The Scientific

\section{World Journal}

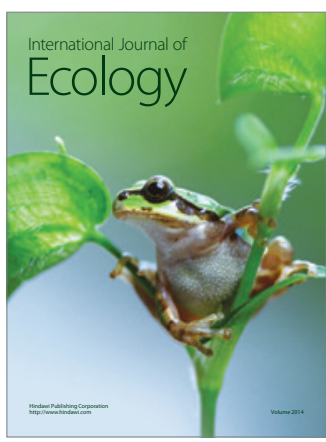

\section{Hindawi}

Submit your manuscripts at

https://www.hindawi.com
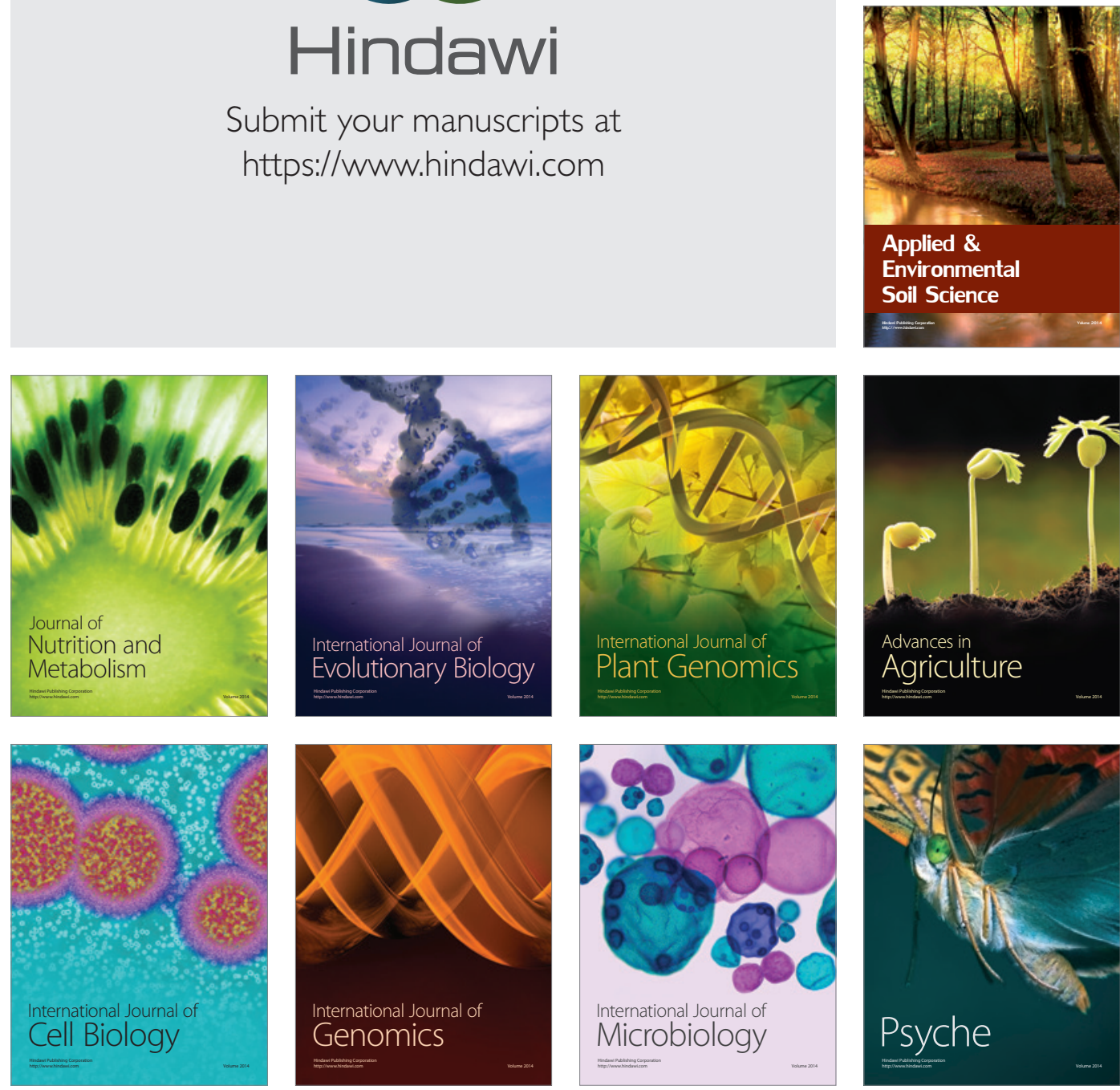
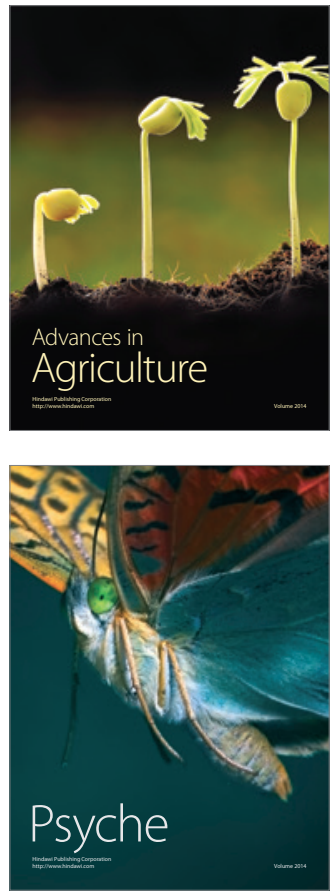